MaPan : Jurnal Matematika dan Pembelajaran

p-ISSN: 2354-6883 ; e-ISSN: 2581-1727

Volume 6, Nomor 1, Juni 2018 (56-69)

DOI: https://doi.org/10.24252/mapan.2018v6n1a6

\title{
PENGEMBANGAN INSTRUMEN TES DIAGNOSTIK PILIHAN GANDA DUA TINGKAT UNTUK MENGIDENTIFIKASI PEMAHAMAN KONSEP MATEMATIKA
}

\author{
Dian Mutmainna1) Sitti Mania2) A. Sriyanti3) \\ 1,2,3Fakultas Tarbiyah dan Keguruan UIN Alauddin Makassar \\ 1,2,3Kampus II: Jalan H. M. Yasin Limpo Nomor 36 Samata-Gowa \\ E-mail: dian.mai95@gmail.com¹), sitti.mania@uin-alauddin.ac.id²), \\ a.sriyanti@uin-alauddin.ac.id ${ }^{3}$ )
}

Submitted: 25-01-2018, Revised: 06-03-2018, Accepted: 20-03-2018

\begin{abstract}
Abstrak:
Penelitian ini bertujuan menghasilkan sebuah instrumen tes diagnostik untuk mengidentifikasi tingkat pemahaman konsep matematika siswa yang berbentuk pilihan ganda dua tingkat. Penelitian ini merupakan penelitian Research \& Development (R \& D) dengan menggunakan model pengembangan Tessmer yang dikenal dengan tipe formatif evaluation. Pengembangan Tessmer terdiri dari 4 tahap yaitu preliminary, self evaluation, tahap prototyping (expert reviews, one-to-one dan small group) dan field test. Angket respon siswa pada instrumen tes diagnostik pilihan ganda dua tingkat memenuhi kriteria tercapai dan tidak ada perbaikan/revisi terhadap instrumen tes yang akan dikembangkan karena lebih dari 50\% siswa yang memberikan respon positif. Dari hasil angket respon siswa dapat diketahui bahwa produk instrumen tes diagnostik ini dapat dikatakan praktis untuk digunakan. Hasil data tes diagnostik pilihan ganda dua tingkat untuk mengidentifikasi pemahaman konsep siswa, dapat diketahui bahwa jumlah siswa yang termasuk dalam kategori paham konsep 58,95\%, persentase siswa yang mengalami miskonsepsi sebesar $12,63 \%$ dan persentase siswa yang tidak paham konsep sebesar $28,25 \%$. Berdasarkan hasil pekerjaan siswa dalam menjawab tes diagnostik pilihan ganda dua tingkat dapat dikatakan bahwa produk instrumen tes ini cukup efektif dalam mengidentifikasi tingkat pemahaman konsep matematika siswa.
\end{abstract}

Kata Kunci: Tes Diagnostik, Pilihan Ganda Dua Tingkat, Pemahaman Konsep Matematika

\section{THE DEVELOPMENT OF DIAGNOSTIC TEST INSTRUMENT OF TWO-LEVEL MULTIPLE CHOICE TO IDENTIFY STUDENTS' UNDERSTANDING ON COMPULSORY MATHEMATICAL CONCEPT IN MAN 1 MAKASSAR}

\begin{abstract}
:
The study is aimed at producing a diagnostic test instrument to identify the level of understanding of mathematical concepts of students in the form of two-level multiple choice. This research is a Research \& Development $(R \& D)$ by using Tessmer development model known as
\end{abstract}

Copyright $@$ 2018, MaPan : Jurnal Matematika dan Pembelajaran 
formative type evaluation. The development of Tessmer consists of four stages: introduction, selfevaluation, prototyping (expert review, one-to-one and small group) and field testing. Questionnaire responses of students on the two-level multiple choice diagnostic test instrument meet the achieved criteria and no improvement/revision of the test instrument to be developed as more than $50 \%$ of the students responded positively. From the questionnaire results of students' response, it can be identified that the product of diagnostic test instrument can be said to be practical to use. The results of the two-level multiple choice diagnostic test instrument data to identify students' concept of understanding can be observed that the students who understand the concept, those who experienced misconceptions, and who do not understand the concept are $58.95 \%, 12.63 \%$, and $28.25 \%$ respectively. Based on the results of the students' work in answering the two-level multiple choice diagnostic test, it can be said that the test instrument product is quite effective in identifying the level of understanding of students' mathematical concepts.

Keywords: Diagnostic Test, Two-Level Multiple Choice, Understanding of Mathematical Concepts

How to Cite: Mutmainnah, D., Mania, S., \& Sriyanti, A. (2018). Pengembangan Instrumen Tes Diagnostik Pilihan Ganda Dua Tingkat untuk Mengidentifikasi Pemahaman Konsep Matematika. MaPan : Jurnal Matematika dan Pembelajaran, 6 (1), 5669.

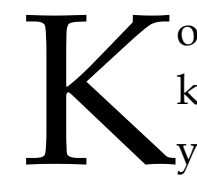

ontribusi pendidikan bagi negara sangat berperan dalam meningkatkan kualitas sumber daya manusia di masa mendatang. Proses pendidikan yang berkualitas akan menghasilkan pendidikan yang sesuai dengan fungsi dan tujuannya. Proses pendidikan merupakan kegiatan sosial atau pergaulan antara pendidik dan peserta didik dengan menggunakan isi atau materi pendidikan, metode, dan alat pendidikan tertentu yang berlangsung dalam suatu lingkungan untuk mencapai tujuan pendidikan yang telah ditetapkan. Dalam mencapai tujuan pendidikan nasional itu diperlukan seperangkat kurikulum yang menunjang untuk diberikan kepada anak didik dalam tingkatan satuan pendidikan masing-masing seperti satuan pendidikan sekolah dasar, satuan pendidikan sekolah menengah pertama dan sekolah menengah atas.

Kurikulum menjadi jembatan untuk menuju tujuan pada setiap satuan pendidikan diuraikan atas beberapa mata pelajaran di sekolah. Salah satu mata pelajaran yang ada dalam silabus baik tingkat dasar sampai dengan tingkat perguruan tinggi adalah matematika. Matematika sangat memegang peranan 
penting karena dapat meningkatkan pengetahuan siswa dalam berpikir secara logis, rasional, kritis, dan efisien. Matematika merupakan ilmu yang terstruktur dan sistematis, artinya konsep dan prinsip dalam matematika memiliki kaitan satu sama lain. Kebanyakan siswa masih menganggap pelajaran matematika sulit, penuh perhitungan yang memusingkan, banyak rumus, simbol, angka serta pelajaran yang membosankan sehingga menimbulkan sikap malas belajar yang ditunjukkan siswa dalam belajar (Supardi, 2014: 81). Hal ini juga sejalan dengan hasil penelitian Trends in International Mathematics and Since Study (TIMMS) tahun 2015, untuk tingkat SMP dan SMA bahwa siswa Indonesia hanya berada pada rangking ke-36 dari 49 negara dalam hal melakukan prosedur ilmiah. Rendahnya mutu pendidikan di Indonesia yang dapat dilihat dari berbagai sisi menunjukkan bahwa belum berhasilnya proses pembelajaran yang dilakukan selama ini.

Salah satu kecenderungan yang menyebabkan siswa gagal dalam mengerjakan soal-soal matematika dengan baik yaitu karena siswa kesulitan dalam memahami konsep dan kurang menggunakan nalar yang baik dalam menyelesaikan soal atau tes yang diberikan. Atas kenyataan itu, semestinya sekolah harus berperan turut membantu memecahkan masalah yang dihadapi siswa sebab pemahaman konsep merupakan aspek yang sangat penting dalam prinsip pembelajaran matematika. Jika seorang siswa memahami konsep yang diajarkan kepadanya maka ia akan mampu menjelaskan kembali konsep tersebut dengan bahasanya sendiri dan mampu menyelesaikan permasalahan atau soalsoal yang berhubungan dengan konsep tersebut (Kiswanto, Rahman, \& Sulasteri, 2015). Demikian juga yang dikemukakan oleh (Fatra, 2017) bahwa seseorang dikatakan paham apabila ia dapat menjelaskan kembali apa yang dipahaminya dengan menggunakan bahasanya sendiri. Oleh sebab itu dibutuhkan sebuah tes diagnostik untuk mengetahui sampai sejauh mana konsep matematika yang dipahami siswa karena tes diagnostik menjadi salah satu alat pengukuran yang baik untuk menilai pemahaman konsep matematika peserta didik, dimana kebanyakan peserta didik kurang begitu memahami konsep ketika diberikan sebuah tes (Suwarto, 2013: 15).

Tes diagnostik berfungsi untuk mengetahui kelemahan-kelemahan siswa sehingga hasil tersebut dapat digunakan sebagai dasar untuk memberikan tindak lanjut berupa perlakuan yang tepat dan sesuai dengan kelemahan yang dimiliki siswa (Susanti, Waskito, \& Surantoro, 2014). Tujuan tes diagnostik adalah untuk 
mengidentifikasi siswa yang mengalami masalah dalam belajar (Nursalam, 2016; Wijaya, Suratno, \& Aminuddin, 2013).

Terdapat beberapa alat diagnostik yang dapat digunakan, yaitu wawancara, pertanyaan terbuka, peta konsep, dan instrumen tes yaitu berbentuk tes uraian atau pilihan ganda dua tingkat, Dari keempat alat diagnostik tersebut tes pilihan ganda dua tingkat sangat cocok untuk mengukur tingkat pemahan konsep siswa.

Tes pilihan ganda dua tingkat memiliki keunggulan karena dalam tes ini selain siswa mengerjakan butir tes yang mengungkapkan konsep tertentu siswa juga harus mengungkapkan alasan kenapa memilih jawaban tersebut. Dengan mengungkapkan alasan mereka dalam menjawab setiap pertanyaan, maka akan diketahui letak miskonsepsi yang terjadi. Tes pilihan ganda dua tingkat ini memiliki dua tingkatan yaitu tingkatan pertama terdiri dari pertanyaan pilihan ganda dengan lima pilihan jawaban, dan tingkatan kedua merupakan alasan jawaban tingkat pertama (Cengiz, 2009). Dalam menyusun two-tier multiple choice item ada beberapa prosedur yang digunakan, yaitu mengidentifikasi isi dan mendapatkan informasi tentang miskonsepsi Widdiharto (2008: 38).

Penelitian ini sangat penting untuk dilaksanakan dengan tujuan dapat membantu para guru dalam mengidentifikasi pemahaman konsep matematika siswa dan tidak hanya sekedar melihat nilai semata yang dijadikan pengukuran kemampuan siswa tanpa melihat dimana letak kesalahan yang mungkin dialami siswa. Terkait dengan penelitian ini peneliti sebelumnya yaitu Resti Nirmala Asih (2011), Dwi Susanti (2014); Baharuddin (2014), Wiwi Siswaningsih (2015); dan Nurhidayati, Tayeb, \& Baharuddin (2017) telah melakukan penelitian berkaitan dengan pengembangan instrumen tes diagnostik pilihan ganda dua tingkat untuk mengidentifikasi tingkat pemahaman konsep siswa.

\section{METODE PENELITIAN}

Penelitian ini merupakan penelitian Research \& Development ( $\mathrm{R} \& \mathrm{D})$ dengan menggunakan model pengembangan Tessmer yang dikenal dengan tipe formatif evaluation. Pengembangan Tessmer terdiri dari 4 tahap yaitu preliminary, self evaluation, tahap prototyping (expert reviews, one-to-one dan small group) dan field test. Berikut merupakan prosedur pengembangan yang dilakukan. 


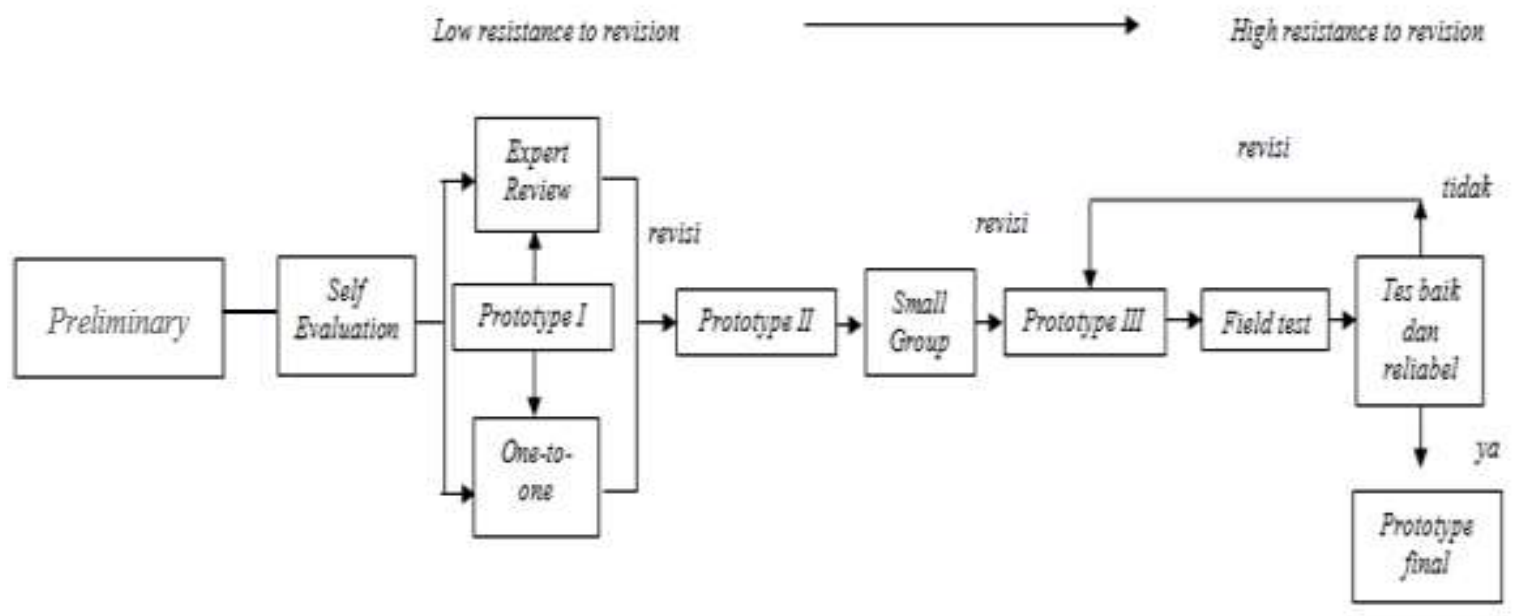

Gambar 1. Model Tipe Fromatife Evaluation Tessmer

Subjek uji coba penelitian yang digunakan adalah siswa kelas XII MIA 1 MAN 1 Makassar pada semester ganjil tahun ajaran 2016/2017. Teknik pengumpulan data terdiri dari tes dan angket. Instrumen pengumpulan data berupa instrumen tes, lembar validasi dan angket. Teknik analisis data terdiri dari validasi instrumen tes diagnostik pilihan ganda dua tingkat, analisis angket respon siswa, uji reliabilitas, analisis tingkat kesukaran, analisis daya pembeda, analisis efektivitas opsi dan analisis tingkat pemahaman konsep matematika siswa.

\section{HASIL PENELITIAN DAN PEMBAHASAN}

\section{Hasil Penelitian}

\section{Validasi Instrumen Tes Diagnostik Pilihan Ganda Dua Tingkat}

Proses judgment validasi isi instrumen tes untuk mengidentifikasi pemahaman konsep matematika dilakukan oleh 3 expert (validator) diantaranya dua orang dosen program studi pendidikan matematika, dan satu orang guru mata pelajaran matemtika. Metode analisis validasi yang digunakan yaitu metode Content Validaty Ratio (CVR) dan Content Validaty Index (CVI). Berdasarkan hasil uji CVR dan CVI menunjukkan bahwa 19 butir soal memiliki hasil CVR dan CVI sebesar 1, sehingga nilai CVR > 0,99 dan berdasarkan kriteria CVI dari 19 butir soal tersebut termasuk kedalam kategori sangat sesuai. 


\section{Analisis Angket siswa}

Hasil dari analisis angket respon siswa pada ujicoba one-to-one diperoleh rata-rata respon positif siswa adalah $79,17 \%$ dan rata-rata respon negatif siswa adalah $20,83 \%$, sedangkan pada ujicoba small group rata-rata respon positif siswa adalah $75 \%$ dan rata-rata respon negatif siswa adalah $25 \%$. Dapat disimpulkan bahwa lebih dari 50\% siswa yang memberikan respon positif, artinya keterbacaan soal sudah baik dan bisa dilanjutkan ke ujicoba field test.

\section{Uji Reliabilitas Instrumen Tes Diagnostik Pilihan Ganda Dua Tingkat}

Berdasarkan hasil uji reliabilitas pada program SPSS versi 20 menunjukkan nilai reliabilitas instrumen tes diagnostik plihan ganda dua tingkat adalah 0,841 dengan interpretasi sangat tinggi. Hal ini menunjukkan bahwa instrumen dikatakan reliabel.

\section{Tingkat Kesukaran Instrumen Tes Diagnostik Pilihan Ganda Dua Tingkat}

Hasil analisis tingkat kesukaran instrumen tes diagnostik pilihan ganda dua tingkat siswa ditunjukkan pada tabel 1.

Tabel 1. Analisis Tingkat Kesukaran Instrumen Tes Diagnostik Pilihan Ganda Dua Tingkat

\begin{tabular}{ccccc}
\hline No & Kategori & Butir Soal & Jumlah & Persentase \\
\hline 1. & Sangat Sukar & 0 & 0 & $0 \%$ \\
\hline 2. & Sukar & 5,18 & 2 & $10 \%$ \\
3. & Sedang & $2,3,4,8,11,12,13,14,15,16,17$, & 12 & $63 \%$ \\
4. & 19 & 5 & $26 \%$ \\
5. & Mudah & $1,6,7,9,10$ & 0 & $0 \%$ \\
& $\begin{array}{c}\text { Sangat } \\
\text { Mudah }\end{array}$ & 0 & & \\
\hline
\end{tabular}

Berdasarkan hasil analisis tingkat kesukaran pada instrumen tes diagnostik pilihan ganda dua tingkat 5 butir soal memiliki tingkat kesukaran dengan kategori "mudah", 12 butir memiliki tingkat kesukaran dengan kategori "sedang", dan 10 butir soal memiliki tingkat kesukaran kategori "sukar". Ratarata tingkat kesukaran yang diperoleh adalah 0,59 dengan kategori sedang, 
artinya tingkat kesukaran instrumen tes diagnostik pilihan ganda dua tingkat secara kesuluruhan cukup baik.

\section{Daya Pembeda Instrumen Tes Diagnostik Pilihan Ganda Dua Tingkat}

Hasil analisis daya pembeda instrumen tes diagnostik pilihan ganda dua tingkat ditunjukkan pada tabel 2.

Tabel 2. Analisis Daya Pembeda Instrumen Tes Diagnostik Pilihan Ganda Dua Tingkat

\begin{tabular}{ccccc}
\hline No & Kategori & Butir Soal & Jumlah & Persentase \\
\hline 1. & Sangat Jelek & 8 & 1 & $5 \%$ \\
2. & Jelek & 0 & 0 & $0 \%$ \\
3. & Cukup & $1,7,9,10,11,14$ & 6 & $31 \%$ \\
4. & Baik & $5,6,13,16,18,19$ & 6 & $31 \%$ \\
5. & Sangat Baik & $2,3,4,12,15,17$ & 6 & $31 \%$ \\
\hline
\end{tabular}

Berdasarkan hasil analisis daya pembeda instrumen tes diagnostik pilihan ganda dua tingkat, maka diperoleh bahwa 6 butir soal memiliki daya pemebeda dengan kategori "cukup", 6 butir soal memiliki daya pembeda dengan kategori "baik", 6 butir soal memiliki daya pembeda dengan kategori "sangat baik" dan terdapat satu butir soal yang memiliki daya pembeda yang sangat jelek. Rata-rata daya pembeda pada soal tes diagnostik pilihan ganda dua tingkat adalah 0,55 dengan kategori baik artinya soal tes diagnostik pilihan ganda dua tingkat mampu mebedakan kemampuan peserta tes yang berkemampuan tinggi dan berkemampuan rendah.

\section{Analisis Efektivitas Opsi Tes Diagnostik Pilihan Ganda Dua Tingkat}

Hasil analisis analisis efektivitas opsi tes diagnostik pilihan ganda dua tingkat ditunjukkan pada tabel 3.

Tabel 3. Analisis Hasil Efektivitas Opsi Tes Diagnostik Pilihan Ganda Dua Tingkat

\begin{tabular}{ccccc}
\hline No & Kategori & Butir Soal & Jumlah & Persentase \\
\hline 1. & Sangat Jelek & 0 & 0 & $0 \%$ \\
2. & Jelek & $3,7,9,11,17,18$ & 6 & $32 \%$ \\
3. & Cukup Baik & $4,5,10,13,14,15,19$ & 7 & $37 \%$ \\
4. & Baik & $1,8,16$ & 3 & $15 \%$ \\
\hline
\end{tabular}




\section{5.} Sangat Baik

2,6

2

$10 \%$

Berdasarkan hasil analisis efektivitas opsi tes diagnostik pilihan ganda dua tingkat menunjukkan bahwa $37 \%$ atau 7 butir soal memiliki opsi yang cukup baik dan tidak ada butir (0\%) soal yang memiliki kualitas opsi yang sangat jelek, meskipun terdapat 6 butir (32\%) soal yang kualitas opsinya jelek. Akan tetapi, tabel 3 juga menunjukkan bahwa terdapat 3 butir $(15 \%)$ soal yang memiliki kualitas opsi yang baik dan bahkan ada 2 butir (10\%) soal yang memiliki kualitas opsi yang sangat baik yakni pada butir soal nomor 2 dan 6. Secara keseluruhan dapat dikatakan bahwa distraktor (pengecoh) cukup berfungsi mengecoh jawaban peserta tes, karena peserta tes pada kelompok siswa yang berkemampuan rendah memilih jawaban yang salah sehingga terkecoh dengan jawaban yang benar.

\section{Analisis Data Hasil Tingkat Pemahaman Konsep Matematika Siswa}

Hasil analisis tingkat pemahaman konsep matematika siswa ditunjukkan pada tabel 4.

Tabel 4. Persentase Paham Konsep, Miskonsepsi dan Tidak Paham Konsep Berdasarkan Nomor Soal

\begin{tabular}{ccccccc}
\hline \multirow{3}{*}{ Nomor Soal } & \multicolumn{9}{c}{ Kriteria } \\
\cline { 2 - 7 } & \multicolumn{2}{c}{ Paham Konsep } & \multicolumn{2}{c}{ Miskonsepsi } & \multicolumn{2}{c}{ Tidak Paham } \\
\cline { 2 - 7 } & F & \% & F & \% & F & $\%$ \\
\hline 1 & 27 & 90 & 0 & 0 & 3 & 10 \\
2 & 15 & 50 & 4 & 13 & 11 & 37 \\
3 & 17 & 57 & 1 & 3 & 12 & 40 \\
4 & 14 & 47 & 4 & 13 & 12 & 40 \\
5 & 9 & 30 & 3 & 10 & 17 & 57 \\
6 & 22 & 73 & 6 & 20 & 2 & 7 \\
7 & 26 & 87 & 2 & 7 & 2 & 7 \\
8 & 16 & 53 & 12 & 40 & 2 & 7 \\
9 & 27 & 90 & 2 & 7 & 1 & 3 \\
10 & 26 & 87 & 2 & 7 & 2 & 7 \\
11 & 20 & 67 & 6 & 20 & 4 & 13 \\
12 & 20 & 67 & 1 & 3 & 9 & 30 \\
13 & 12 & 40 & 6 & 20 & 12 & 40 \\
14 & 16 & 53 & 2 & 7 & 12 & 40 \\
15 & 18 & 60 & 2 & 7 & 10 & 33 \\
\hline
\end{tabular}

Volume 6, No 1, June 2018 | 63 


\begin{tabular}{ccccccc}
\hline 16 & 11 & 37 & 5 & 17 & 14 & 47 \\
17 & 19 & 63 & 3 & 10 & 8 & 27 \\
18 & 8 & 27 & 5 & 17 & 17 & 57 \\
19 & 13 & 43 & 6 & 20 & 11 & 37 \\
Jumlah & 336 & 1120 & 72 & 240 & 161 & 537 \\
Rata-rata & 17,68 & 58,95 & 3,79 & 12,63 & 8,47 & 28,25 \\
\hline
\end{tabular}

Berdasarkan tabel 4, menunjukkan bahwa persentase siswa yang paham konsep dari hasil penelitian ini sebesar $58,95 \%$, persentase siswa yang mengalami miskonsepsi sebesar $12,63 \%$ dan persentase siswa yang tidak paham konsep sebesar 28,25\%. Dari tabel tersebut dapat dilihat bahwa persentase siswa yang paham konsep, miskonsepsi dan tidak paham konsep pada setiap nomor soal sangat beragam, maka dari itu untuk lebih jelasnya dapat dilihat pada grafik perbandingan paham konsep, miskonsepsi dan tidak paham konsep berikut ini.

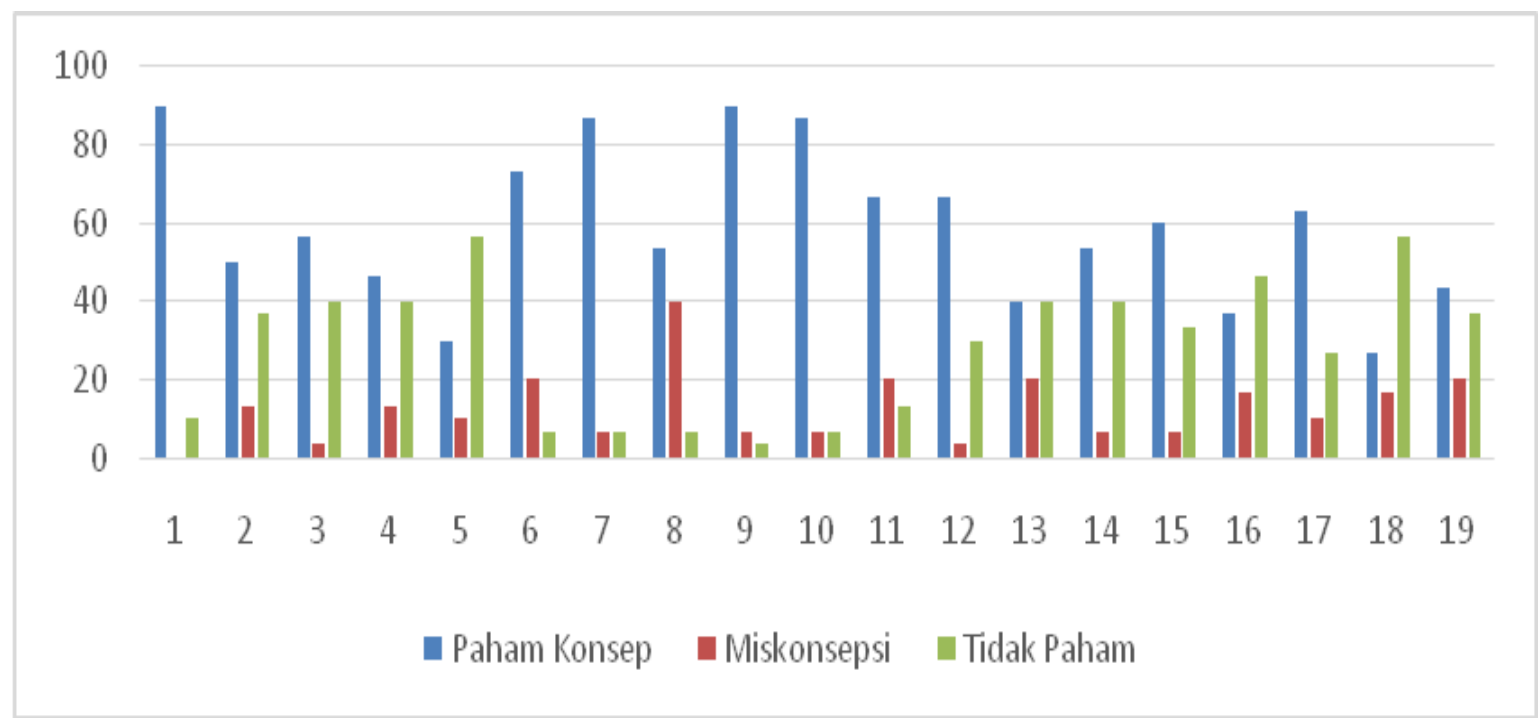

Gambar 2. Grafik Perbandingan Persentase Paham Konsep, Miskonsepsi dan Tidak Paham Konsep

Dari grafik tersebut dapat dilihat bahwa persentase miskonsepsi pada setiap nomor soal berbeda-beda. Rata-rata persentase miskonsepsi yang terjadi paling tinggi adalah pada sub pokok materi transformasi geometri yaitu dari nomor 16-19 dengan indikator pemahaman konsep yaitu kemampuan mengubah suatu bentuk representasi ke bentuk lainnya dan persentase miskonsepsi yang 
terkecil adalah pada sub pokok materi program linear. Hal ini dikarenakan banyaknya siswa belum memahami konsep transformasi geometri utamanya pada merepresentasikan sebuah koordinat bayangan, sedangkan untuk materi program linear sebagian besar peserta tes menjawab benar pada setiap soal yang ada sebab untuk materi ini konsep yang harus diterapkan tidak banyak seperti konsep subtitusi-eliminasi dimana konsep ini memang sangat sering digunakan dalam pembelajaran matematika dimana siswa sudah terbiasa mengerjakan soal dengan tipe seperti ini. Selain itu, dapat diketahui bahwa butir soal yang memiliki nilai persentase miskonsepsi paling tinggi yaitu sebesar $40 \%$ adalah butir soal nomor 8 dengan indikator pemahaman konsep yaitu kemampuan mendefinisikan konsep secara verbal dan tulisan, butir soal ini memiliki persentase miskonsepsi paling tinggi sebab dilihat dari jawaban peserta tes, kebanyakan peserta tes salah dalam mengaplikasikan konsep transpose matriks dan operasi perkalian matriks, sehingga hasil yang mereka dapat tidak sesuai dengan pilihan jawaban yang tepat.

\section{Pembahasan}

Pengembangan instrumen tes diagnostik pilihan ganda dua tingkat untuk mengidentifikasi pemahaman konsep siswa telah melalui serangkaian fase pengembangan model Tessmer mulai dari tahap preliminary, self evaluation, tahap prototyping (expert review, one-to-one, small goup) dan field test yang menghasilkan sebuah produk. Produk yang dimaksud adalah instrumen tes diagnostik pilihan ganda dua tingkat berjumlah 19 soal. Sebelum proses pengembangan dilakukan, telah ditetapkan suatu kriteria kualitas instrumen tes untuk melihat sejauh mana keberhasilan produk yang dihasilkan.

Berdasarkan hasil yang diperoleh yaitu penilaian ahli dan validasi serta uji coba lapangan, instrumen tes yang dihasilkan mencapai kriteria yang telah ditetapkan, yatu valid dan reliable, sedangkan tingkat kesukaran instrumen tes dan daya pembeda instrumen tes secara keseluruhan sudah baik. Berdasarkan hasil data tes diagnostik pilihan ganda dua tingkat untuk mengidentifikasi pemahaman konsep siswa, dapat diketahui bahwa jumlah siswa yang termasuk dalam kategori paham konsep 58,95\%, persentase siswa yang mengalami miskonsepsi sebesar $12,63 \%$ dan persentase siswa yang tidak paham konsep sebesar $28,25 \%$. Dari hasil tes dapat diketahui bahwa kemampuan siswa dalam memahami konsep cukup baik terbukti dari banyaknya persentase peserta tes 
yang paham konsep dibandingkan dengan yang miskonsepsi dan tidak paham konsep, namun ada beberapa siswa yang mengalami miskonsepsi dan tidak paham konsep terhadap butir soal atau materi tertentu. Hasil tes tersebut menunjukkan bahwa tes diagnostik yang dikembangkan mampu mengidentifikasi tingkat pemahaman konsep siswa, dapat dilihat dari berapa siswa yang teridentifikasi miskonsepsi, tidak paham konsep ataupun paham konsep. Tes diagnostik harus dapat memberikan gambaran akurat tentang kesulitan yang dimiliki siswa berdasarkan informasi kesalahan yang dibuatnya. Tes diagnostik digunakan untuk menilai pemahaman konsep siswa terhadap konsep-konsep kunci (key concepts) pada topik tertentu, dan secara khusus untuk konsep-konsep yang cenderung kurang dipahami dengan baik, sehingga dari hasil tes diagnostik ini terlihat pada materi tertentu siswa mengalami miskonsepsi yang paling banyak melalui analisis tingkat pemahaman konsep.

Hasil analisis pemahaman konsep siswa menunjukkan bahwa butir soal yang paling banyak persentase miskonsepsinya adalah soal nomor 8 dengan persentase miskonsepsi sebesar $40 \%$ atau sebanyak 12 dari 30 peserta tes yang mengalami miskonsepsi pada soal ini, sebab dari analisis jawaban siswa sulit dalam membedakan cara operasi penjumlahan dan perkalian matriks, sedangkan materi yang paling tinggi persentase miskonsepsinya adalah pada materi transformasi geometri dari butir soal nomor 16 sampai dengan 19 yaitu sebesar $16 \%$. Materi ini memang terbilang cukup sulit pada pengaplikasian konsepnya, siswa seringkali belum paham dalam menafsirkan konsep rotasi, relasi, translasi dan refleksi. Banyaknya miskonsepsi pada materi ini membuktikan bahwa siswa tidak memahami konsep yang diajarkan. Berdasarkan hasil observasi dan wawancara diperoleh bahwa miskonsepsi pada konsep ini berasal dari metode pembelajaran yang diterapkan oleh guru dan buku referensi luar sekolah.

Kecepatan siswa dalam memahami konsep juga bergantung kepada metode dan cara penyampaian guru saat mengajar di kelas. Metode yang tepat serta cara penyampaian yang menarik membuat siswa lebih cepat paham terhadap konsep yang diajarkan, begitupula sebaliknya. Selain itu, kemampuan siswa yang rendah juga merupakan faktor dari terjadinya miskonsepsi pada siswa. Oleh karena kemampuan yang terbatas maka siswa menjadi kurang cepat dalam memahami konsep, sehingga menimbulkan miskonsepsi atau benar-benar tidak memahami konsep. Mata pelajaran matematika menekankan pada konsep Murizal (2012), artinya dalam mempelajari matematika peserta didik harus 
memahami konsep matematika terlebih dahulu agar dapat menyelesaikan soalsoal dan mampu mengaplikasikan pembelajaran tersebut di dunia nyata dan mampu mengembangkan kemampuan lain yang menjadi tujuan dari pembelajaran matematika. Namun dari hasil penelitian ini secara garis besar dapat dikatakan bahwa rata-rata siswa memahami konsep materi yang diujikan walaupun ada beberapa siswa yang mengalami miskonsepsi ataupun benarbenar tidak memahami konsep.

\section{SIMPULAN}

Berdasarkan hasil data tes diagnostik pilihan ganda dua tingkat untuk mengidentifikasi pemahaman konsep siswa, dapat diketahui bahwa jumlah siswa yang termasuk dalam kategori paham konsep 58,95\%, persentase siswa yang mengalami miskonsepsi sebesar $12,63 \%$ dan persentase siswa yang tidak paham konsep sebesar 28,25\%. Dari hasil pekerjaan siswa dalam menjawab tes diagnostik pilihan ganda dua tingkat dapat dikatakan bahwa produk instrumen tes ini cukup efektif dalam mengidentifikasi tingkat pemahaman siswa, sebab dapat diketahui bahwa kemampuan siswa dalam memahami konsep cukup baik terbukti dari banyaknya persentase peserta tes yang paham konsep dibandingkan dengan yang miskonsepsi dan tidak paham konsep, namun ada beberapa siswa yang mengalami miskonsepsi dan tidak paham konsep terhadap butir soal atau materi tertentu. Instrumen tes yang dikembangkan secara keseluruhan termasuk dalam kualitas baik dilihat dari validitas, reliabilitas, daya pembeda serta tingkat kesukarannya. Tes yang dikembangkan memiliki indeks validitas isi (CVI) sebesar 1,00 dan reliabilitas sebesar 0,84 dengan kategori sangat tinggi. Angket respon siswa pada instrumen tes diagnostik pilihan ganda dua tingkat pada uji one to one diperoleh rata-rata respon positif siswa adalah $70,8 \%$ dan rata-rata respon negatif siswa adalah $20,9 \%$, sedangkan pada ujicoba small group rata-rata respon positif siswa adalah $70,8 \%$ dan rata-rata respon negatif siswa adalah 29,2\%, sehingga angket respon siswa memenuhi kriteria "tercapai" dan tidak ada perbaikan/revisi terhadap instrumen tes yang akan dikembangkan karena lebih dari 50\% siswa yang memberikan respon positif. Dari hasil angket respon siswa dapat diketahui bahwa produk instrumen tes diagnostik ini dapat dikatakan praktis untuk digunakan, namun untuk mengetahui lebih lanjut baik atau tidaknya instrumen tes yang telah dikembangkan, maka disarankan pada peneliti selanjutnya agar dapat menguji 
cobakan pada subjek uji coba yang lebih luas serta soal yang dibuat harus disesuaikan dengan waktu yang tersedia.

\section{DAFTAR PUSTAKA}

Baharuddin. (2014). Pengembangan perangkat pembelajaran matematika materi segiempat berbasis model kooperatif tipe STAD dengan metode penemuan terbimbing kelas VII MTS Negeri Model Makassar, MaPan : Jurnal Matematika dan Pembelajaran, 2 (1), 31-51.

Fatra, M. (2017). Implementasi pendekatan matematika realistik menggunakan bahan ajar geometri berbentuk cerita terhadap kemampuan pemahaman konsep dan pemecahan masalah siswa. Tanzhim, 1(01), 110-121.

Hartatiana, H. (2015). Pengembangan soal pemecahan masalah berbasis argumen untuk siswa kelas V Di SD Negeri 79 Palembang. Jurnal Pendidikan Matematika, 8 (2), 76-85.

Kiswanto, K., Rahman, U., \& Sulasteri, S. (2015). Deskripsi pemahaman konsep materi geometri ditinjau dari kepribadian sensing dan intuition pada siswa kelas IX SMPN 33 Makassar. MaPan: Jurnal Matematika dan Pembelajaran, 3 (1), 41-58.

Murizal, A. (2012). Pemahaman konsep matematis dan model pembelajaran quantum teaching. Jurnal Pendidikan Matematika, 1 (1), 19-23.

Nurhidayati, S., Tayeb, T., \& Baharuddin. (2017). Pengembangan bahan ajar matematika berbasis masalah untuk memfasilitasi pencapaian kemampuan penalaran pada pokok bahasan perbandingan kelas VII MTSN Model Makassar. MaPan: Jurnal Matematika Dan Pembelajaran, 5 (2), 236-250.

Nursalam, N. (2016). Diagnostik kesulitan belajar matematika: Studi pada siswa SD/MI di Kota Makassar. Lentera Pendidikan : Jurnal Ilmu Tarbiyah dan Keguruan, 19 (1), 1-15.

Silva, E. Y., Zulkardi, Z., \& Darmawijoyo, D. (2013). Pengembangan soal matematika model PISA pada konten uncertainty untuk mengukur kemampuan pemecahan masalah matematika siswa sekolah menengah 
pertama. Jurnal Pendidikan Matematika, 5(1).

Subekti, F. E., \& Widiyanti, R. A. (2014). Pengembangan instrumen tes Kalkulus Lanjut 2 berbasis pemecahan masalah. Khazanah Pendidikan, 7 (1).

Supardi, U. S. (2014). Peran kedisiplinan belajar dan kecerdasan matematis logis dalam pembelajaran matematika. Jurnal Formatif Unindra, 4 (2), 80-88.

Susanti, D., Waskito, S., \& Surantoro, S. (2014). Penyusunan instrumen tes diagnostik miskonsepsi fisika SMA Kelas XI pada materi usaha dan energi. Jurnal Pendidikan Fisika, 2 (2).

Suwarto. (2013). Pengembangan tes diagnostik dalam pembelajaran. Yogyakarta: Pustaka Pelajar.

Tüysüz, C. (2009). Development of two-tier diagnostic instrument and assess students' understanding in chemistry. Scientific Research and Essays, 4 (6), 626-631.

Widdiharto, R. (2008). Diagnosis kesulitan belajar matematika SMP dan alternatif proses remidinya. Yogyakarta: Pusat Pengembangan dan Pemberdayaan Pendidik dan Tenaga Kependidikan Matematika.

Wijaya, M. H., Suratno, S., \& Aminuddin, H. P. (2013). Pengembangan tes diagnostik mata pelajaran IPA SMP. Jurnal Penelitian Dan Evaluasi Pendidikan, 17 (1), 19-36. 